\title{
EVIDENCE FOR A PREIMPLANTATION RISE IN OESTRADIOL-17 $\beta$ LEVELS ON DAY 4 OF PREGNANCY IN THE MOUSE
}

\author{
J. T. MaCORMAGK* AND G. S. GREENWALD \\ Departments of Obstetrics and Gynecology and Anatomy, \\ University of Kansas Medical Center, Kansas City, Kansas 66103, U.S.A.
}

(Received 22nd Fanuary 1974)

\begin{abstract}
Summary. Measured by radioimmunoassay, the peripheral plasma oestradiol concentration reached a peak $(21 \cdot 2 \pm 1 \mathrm{pg} / \mathrm{ml})$ between 10.00 to 12.00 hours on Day 4 of pregnancy in mice. These values were significantly different from all others measured between 07.00 and 18.00 hours. To determine the physiological significance of this peak, ovariectomies were performed at selected intervals. Ovariectomy at 08.00 hours or earlier usually prevented implantation. The period from 10.00 to 12.00 hours on Day 4 was found to represent a critical time period before which insufficient oestrogen is secreted, in most instances, to initiate implantation.
\end{abstract}

\section{INTRODUCTION}

Krehbiel (1941) showed that a single dose of oestrogen initiated implantation in pregnant lactating rats. This suggested that progesterone priming is followed by a preimplantation surge of oestrogen which mediates nidation (Mayer, 1959, 1963; Shelesnyak, 1960). Implantation can be induced in the ovariectomized pregnant rat or mouse by a single injection of oestrogen (Cochrane \& Meyer, 1957; Canivenc \& Laffargue, 1957; Bloch, 1958; Smith \& Biggers, 1968; Hedlund \& Nilsson, 1971), and can also be initiated in the ovariectomized pregnant rat by administration of smal? out frequent doses of oestrogen and progesterone (DeFeo, 1963; Zeilmaker, 1963). Finn \& Martin (1969) treated ovariectomized pregnant mice with various regimens of progesterone and oestrogen in attempts to simulate the pattern of uterine mitoses observed during early pregnancy. From their results, they postulated that progesterone and oestrogen secretion began about $48 \mathrm{hr}$ after mating and continued (possibly increasing) until after implantation was initiated. A preimplantation increase of oestrogen occurs on Day 4 of pregnancy in the rat (Shaikh, 1971) but this has not been correlated with the effects of ovariectomy.

The availability of a sensitive and specific antibody to oestradiol-17 $\beta$ (Exley, Johnson \& Dean, 1971) has facilitated the measurement of levels of oestradiol in the pregnant mouse by radioimmunoassay (McCormack \&

* Present address: Department of Physiology, University of Pittsburgh, School of Medicine, Pittsburgh, Pennsylvania 15261, U.S.A. 
Greenwald, 1974). As an extension of these studies, the present study was designed to investigate the rôle of oestrogen as a stimulus for blastocyst implantation by determining the peripheral pattern of oestradiol on Day 4 of pregnancy in the mouse in conjunction with the effects on subsequent nidation of varying the time of ovariectomy on Day 4.

\section{MATERIALS AND METHODS}

Sexually mature virgin Swiss fernale mice ( 35 to $40 \mathrm{~g}$ ) were maintained on a 14-hr light/10-hr dark schedule (lights on 06.00 to 20.00 hours) and were placed two to a cage with a male of proven fertility. Females were checked each morning for the presence of a copulatory plug. The day on which one was found was designated Day 1 of pregnancy.

On Day 4, six females were anaesthetized with ether and bled from the abdominal aorta at hourly intervals $( \pm 5 \mathrm{~min})$ from 06.00 to 18.00 hours. Blood was collected in heparinized disposable plastic syringes fitted with a 27-gauge needle. Blood samples were placed in $10 \times 75 \mathrm{~mm}$ disposable glass culture tubes and were centrifuged at $1400 \mathrm{~g}$. The plasma was removed and frozen at $-20^{\circ} \mathrm{C}$ until it was assayed.

The radioimmunoassay used to measure oestradiol-17 $\beta$ has been described previously (McCormack \& Greenwald, 1974). In brief, the antiserum was produced with hapten 17 $\beta$-oestradiol-6-(O-carboxy-methyl)oxime-bovine serum albumin which accounted for its high degree of specificity (Exley $e t$ al., 1971). Cross-reactivity with oestrone averaged less than $1 \%$. The lower limit of sensitivity of the standard curve was $2.5 \mathrm{pg}$. Duplicate water blanks yielded values of $1 \cdot 1 \pm 0 \cdot 1 \mathrm{pg} / \mathrm{ml}$ and plasma from ovariectomized mice, used to determine the non-specific binding effects of plasma, averaged $5 \cdot 8 \pm 0.3 \mathrm{pg} / 500 \mu \mathrm{l}$. The results were analysed by Duncan's New Multiple Range Test (Steel \& Torrie, 1960).

Ovariectomies were performed at $06.00,08.00,11.00,14.00$ and 16.00 hours on Day 4 of pregnancy. A single dorsal incision was made under ether anaesthesia and care was taken not to touch the uterine cornua. Ovariectomized animals were injected subcutaneously with $2 \mathrm{mg}$ progesterone/day from Days 4 to 7 . The progesterone was dissolved in $0.1 \mathrm{ml}$ of peanut oil. Animals were killed on Day 8 and the uteri were inspected for implantation sites. Uteri without gross implantation sites were flushed with saline and the fluid was examined for free blastocysts to determine whether the mouse had been pregnant at the time of ovariectomy.

\section{RESULTS}

\section{Oestradiol-17 $\beta$ levels on Day 4 of pregnancy}

Oestradiol concentration in peripheral plasma was relatively unchanged between 07.00 and 09.00 hours on Day 4 of pregnancy (Table 1). The oestrogen levels began to rise at 10.00 hours, reached a peak $(21 \mathrm{pg} / \mathrm{ml})$ at 11.00 hours, and reverted to lower values by 13.00 hours; thereafter, the values remained approximately the same up to 18.00 hours (Table 1). The oestradiol levels 
Table 1. Oestradiol-17 $\beta$ plasma levels between 07.00 and 18.00 hours on Day 4 of pregnancy in the mouse

\begin{tabular}{c|c}
\hline $\begin{array}{c}\text { Time of collection } \\
\text { of plasma samples } \\
\text { on Day } 4 \text { (hours) }\end{array}$ & $\begin{array}{c}\text { Oestradiol }-17 \beta(\mathrm{pg} / \mathrm{ml}) \\
(\text { mean } \pm S . E .)\end{array}$ \\
\hline 07.00 & $14 \cdot 2 \pm 1 \cdot 0^{*}$ \\
08.00 & $15 \cdot 1 \pm 1 \cdot 0^{*}$ \\
09.00 & $15 \cdot 7 \pm 0 \cdot 3^{*}$ \\
10.00 & $18 \cdot 5 \pm 1 \cdot 0$ \\
11.00 & $21 \cdot 2 \pm 1 \cdot 0$ \\
12.00 & $17 \cdot 3 \pm 0 \cdot 7$ \\
13.00 & $14 \cdot 5 \pm 1 \cdot 4^{*}$ \\
$14 \cdot 00$ & $12 \cdot 6 \pm 0 \cdot 5^{*}$ \\
15.00 & $16 \cdot 8 \pm 0 \cdot 5^{*}$ \\
16.00 & $15 \cdot 0 \pm 0 \cdot 5^{*}$ \\
$17 \cdot 00$ & $12 \cdot 7 \pm 0 \cdot 6^{*}$ \\
18.00 & $15 \cdot 5 \pm 0 \cdot 3^{*}$ \\
\hline
\end{tabular}

There were six animals in each group.

* Significantly different from the values at 10.00 , 11.00 and 12.00 hours at $P<0.01$ by Duncan's New Multiple Range Test.

from 10.00 to 12.00 hours were significantly different from all other values by Duncan's New Multiple Range Test $(P<0.01)$.

The effect of ovariectomy on Day 4 of pregnancy on implantation by Day 8

Bilateral ovariectomy at 06.00 hours, followed by daily progesterone treatment, resulted in implantation in only one mouse; free blastocysts were recovered from the remaining mice in this group (Table 2). From 08.00 hours and thereafter, the percentage of ovariectomized mice with implantation sites increased. Spaying at 11.00 hours represented a transitional time; $50 \%$ of the mice had implantation sites and unimplanted blastocysts were recovered from the remainder. Ovariectomy at 14.00 or 16.00 hours resulted in implantation respectively in $66 \%$ and $75 \%$ of the mice. The latter percentage was not

Table 2. Effect of ovariectomy of mice at selected times on Day 4 of pregnancy

\begin{tabular}{c|c|c|c}
\hline $\begin{array}{c}\text { Time of } \\
\text { ovariectomy } \\
\text { on Day 4 } \\
\text { (hours) }\end{array}$ & $\begin{array}{c}\text { No. of } \\
\text { mice }\end{array}$ & $\begin{array}{c}\text { No. of mice with } \\
\text { implantation sites } \\
\text { on Day 8 (\%) }\end{array}$ & $\begin{array}{c}\text { No. of mice with } \\
\text { free blastocysts } \\
\text { on Day 8 (\%) }\end{array}$ \\
\hline 06.00 & 9 & $1(11 \cdot 1)$ & $8(88 \cdot 8)$ \\
08.00 & 12 & $3(25 \cdot 0)$ & $9(75 \cdot 0)$ \\
11.00 & 10 & $5(50.0)$ & $5(50 \cdot 0)$ \\
14.00 & 9 & $6(66 \cdot 6)$ & $3(33 \cdot 3)$ \\
16.00 & 12 & $9(75 \cdot 0)$ & $3(25 \cdot 0)$ \\
\hline Intact controls & 20 & $16(80 \cdot 0)$ & $2(10 \cdot 0) *$ \\
\hline
\end{tabular}

* Does not include the two animals lacking implantation sites and free blastocysts. 
significantly different from the $80 \%$ observed in intact control mice on Day 8 of pregnancy.

\section{DISCUSSION}

Peripheral levels of oestradiol-17 $\beta$ were low on Day 4 of pregnancy, and the peak observed between 10.00 and 12.00 hours, although significantly different from the other times sampled, did not constitute a marked 'surge'. The mouse is known, however, to be very sensitive to exogenous oestrogen, requiring as little as 5 to $7 \mathrm{ng}$ to elicit an effect (Finn \& Martin, 1969). In addition, the peripheral plasma concentration of oestradiol in mice during pregnancy (McCormack \& Greenwald, 1974) rarely exceeds $60 \mathrm{pg} / \mathrm{ml}$, in contrast to the hamster in which a peripheral plasma concentration of $125 \mathrm{pg}$ oestradiol $/ \mathrm{ml}$ may be found (Baranczuk \& Greenwald, 1974). It seems likely, therefore, that even though the 'surge' is not dramatic it may be of physiological consequence.

To determine the physiological significance of the oestradiol peak on Day 4, ovariectomies were performed at selected intervals, thereby removing the presumed source of oestrogen which is essential for implantation in the mouse (Humphrey, 1967). The results in Table 2 indicate that ovariectomy at 08.00 hours or earlier usually prevents implantation. Furthermore, the period from 10.00 to 12.00 hours on Day 4 appears to be critical; before this time, insufficient oestrogen is secreted, in most instances, to initiate implantation. These results agree with the report of Humphrey (1967) that when mice were ovariectomized at various times on Day 4 the percentage of implantations found on Day 8 progressively increased to the percentage found in controls subjected to sham operation.

Of twenty intact pregnant mice killed on Day 8 , four did not have grossly evident embryonic swellings, and of these four mice, two were found to have free blastocysts in the uterus.

Yoshinaga \& Adams (1966) spayed mice between 10.00 and 13.00 hours on the first 5 days of pregnancy and administered exogenous progesterone. All animals were killed on Day 8 and were inspected for implantation sites. In animals spayed on Days 1, 2, 3 and 4, the percentages with implantation sites were, respectively, 38, 33, 0 and $71 \%$. The implantation occurring in animals ovariectomized on Days 1 and 2 are difficult to explain in the light of the evidence presented here. The fact that none of the animals spayed on Day 3 had implantation sites agrees well with our results; these animals had not been exposed to sufficient oestrogen stimulation for nidation. Clearly, most of the mice examined by Yoshinaga \& Adams on Day 4 were ovariectomized after the critical period during which they received sufficient oestrogen stimulation for implantation.

\section{AGKNOWLEDGMENTS}

This study was supported by grants from NIH (HD 00596) and the Ford Foundation. One of us (J.T.M.) was supported by a Ford Foundation training grant in Reproductive Biology. 


\section{REFERENCES}

Baranczuk, R. \& Greenwald, G. S. (1974) Plasma levels of oestrogen and progesterone in pregnant and lactating hamsters. F. Endocr. (in press).

BLOCH, S. (1958) Experimental research on the hormonal basis of implantation in mammals. Experientia, $14,447$.

Ganivenc, R. \& Laffargue, M. (1957) Survie des blastocystes du rat en l'absence d'hormones ovariennes. C. r. hebd. Séanc. Acad. Sci., Paris, 245, 1752.

Cochrane, R. L. \& Meyer, R. K. (1957) Delayed nidation in the rat induced by progesterone. Proc. Soc. exp. Biol. Med. 96, 155.

DeFeo, V. J. (1963) Temporal aspects of uterine sensitivity in the pseudopregnant or pregnant rat. Endocrinology, 72, 305.

Exiey, D., Johnson, M. W. \& Dean, P. D. G. (1971) Antisera highly specific for $17 \beta$-oestradiol. Steroids, $18,605$.

Finn, G. A. \& Martin, L. (1969) Hormone secretion during early pregnancy in the mouse. F. Endocr. $45,57$.

Hedlund, K. \& Nilsson, O. (1971) Hormonal requirements for the uterine attachment reaction and blastocyst implantation in the mouse, hamster and guinea-pig. F. Reprod. Fert. $26,267$.

Humphrey, K. W. (1967) The induction of implantation in the mouse after ovariectomy. Steroids, 10, 591.

KREHBiEL, R. H. (1941) The effects of theelin on delayed implantation in the pregnant lactating rat. Anat. Rec. 81, 381.

MaCormack, J. T. \& Greenwald, G. S. (1974) Progesterone and oestradiol-17 $\beta$ concentrations in peripheral plasma during pregnancy in the mouse. 7 . Endocr. 62, 101.

MAYER, G. (1959) Recent studies on the hormonal control of delayed implantation and super-implantation in the rat. Mem. Soc. Endocr. 6, 76.

MAYER, G. (1963) Delayed nidation in the rat: a method of exploring the mechanisms of ovo-implantation. In Delayed Implantation, pp. 213-231. Ed. A. C. Enders. University of Chicago Press.

Shaixh, A. A. (1971) Estrone and estradiol levels in the ovarian venous blood from rats during the estrous cycle and pregnancy. Biol. Reprod. 5, 297.

Shelesnyak, M. C. (1960) Nidation of the fertilized ovum. Endeavour, 18, 91.

SMTTH, D. M. \& BigGers, J. D. (1968) The oestrogen requirement for implantation and the effect of its dose on the implantation response in the mouse. 7. Endocr. 41, 1.

Steel, R. G. D. \& Torrie, J. H. (1960) Principles and Procedures of Statistics. McGraw-Hill, New York.

YoshinaGA, K. \& Adams, G. E. (1966) Delayed implantation in the spayed, progesterone treated adult mouse. 7. Reprod. Fert. 12, 593.

Zeilmaker, G. H. (1963) Experimental studies on the effect of ovariectomy and hypophysectomy on blastocyst implantation in the rat. Acta endocr., Copenh. 44, 355. 